\title{
Chemostratigraphy of the Upper Jurassic (Oxfordian) Smackover Formation for Little Cedar Creek and Brooklyn Fields, Alabama
}

\author{
Rian A. Engle ${ }^{1}$, Lance D. Yarbrough ${ }^{2 *}$, and Greg Easson ${ }^{3}$ \\ 1 Naval Oceanographic Office, Naval Meteorology and Oceanography Command, 1100 Balch Blvd, Stennis \\ Space Center, Mississippi, USA \\ 2 Department of Geology \& Geological Engineering, 120A Carrier Hall, The University of Mississippi, \\ University, Mississippi, USA; ldyarbro@olemiss.edu \\ 3 Mississippi Mineral Resource Institute, 111 Brevard Hall, The University of Mississippi, University, \\ Mississippi, USA; geasson@olemiss.edu \\ * Correspondence: ldyarbro@olemiss.edu; Tel.: +1-662-915-7498
}

\begin{abstract}
The Upper Jurassic (Oxfordian Age) Smackover Formation is a significant source for hydrocarbon production in southwest Alabama. Brooklyn Field is in southeast Conecuh County, Alabama and has been a major producer of oil and natural gas for the state. The Smackover is a carbonate formation that is divided into seven distinct lithofacies. In southwest Alabama, the Smackover Formation is heavily influenced by paleotopography from the underlying Paleozoic rocks of the Appalachian system. The goal of this study is to determine elemental ratios in rock core within the Smackover Formation using a X-ray fluorescence (XRF) handheld scanner, to correlate between lithofacies in the Smackover Formation and elementally characterize the upper oolitic grainstone reservoir and the lower thrombolite boundstone. Eight wells were used for the study within Brooklyn Field and Little Cedar Creek fields. Cores from the eight wells were scanned on six-inch intervals. Chemical logs were produced to show elemental weights in relation to depth and lithofacies. Well data collected for chemical signatures within producing zones were correlated to reservoir lithofacies and porosity. Aluminum, silicon, calcium, titanium, and iron were the most significant ( $>95 \%$ confidence level) predictors of porosity and is related to the depositional environment and subsequent diageneses of the strata. XRF data suggests relative enrichments in iron, titanium, and potassium may be related to deposition in relatively restricted marine waters.
\end{abstract}

Keywords: $\mathbf{x}$-ray fluorescence, paleo-depositional environments; porosity correlation

\section{Introduction}

The Upper Jurassic (Oxfordian Age) Smackover Formation is a significant source for hydrocarbon production in southwest Alabama. Little Cedar Creek and Brooklyn fields are in southeast Conecuh County, Alabama and have been a major producer of oil and natural gas. Both fields together contain 79 producing wells more than 4,500 acres. To date, total production of fields includes 59.400 million cubic feet (MMCF) of natural gas and 42.748 million barrels (MMbbl) of oil [1]. Exploration for Smackover Formation production in Alabama is primarily based on seismic profiles to target microbial buildups overlying paleo topographic highs of Paleozoic basement material [2].

The purpose of this study was to determine if abundances of various chemical elements could be related to hydrocarbon production characteristics within the Smackover Formation in Little Cedar Creek and Brooklyn fields. Elemental concentration commonly used in chemostratigraphy can produce signatures that may be unique to the basin or a formation. These signatures can be used to better understand the stratigraphy and improve petroleum reservoir development. In this study, we collected high-resolution elemental scans of core using X-ray fluorescence (XRF) to capture rock 
properties from core analysis. Elemental logs can be generated and compared to petrophysical logs for advanced well logging, chemostratigraphy, and reservoir characterization within Little Cedar Creek and Brooklyn fields. During the exploration and drilling process, statistical analysis and detailed mapping can be applied throughout the field and basin.

\section{Geologic Setting}

The Gulf of Mexico began to develop during the Late Triassic as a result of the initiation of rifting within the North American Plate and detachment from the African Plate and South American Plate [3]. This period of rifting continued until the Middle Jurassic and is recognized as the first of two distinct techno-stratigraphic periods in the Gulf of Mexico. During the first period, rifting from the Late Triassic to the end of the Middle Jurassic was active. Tectonic development from subsiding grabens and rift basins in the region controlled stratigraphic events. Thick sequences of nonmarine clastics and associated volcanics characterized this period of rifting [3]. A second period of rifting that followed occurred during Late Jurassic. Prolonged subsidence in the central portion of the Gulf of Mexico was rimmed by stable shelves and ramps composed of shales and limestones. These sedimentary units defined the Upper Jurassic sequence [3].

Southwest Alabama is located on the northern perimeter of the Gulf of Mexico basin (Figure 1). Sedimentary units in this region are a result of the continuous deposition that occurred from the Jurassic Period to the present-day. Paleozoic rocks of the Appalachian system uncomformably underlie the Mesozoic and Cenozoic formations [4].

This ultimately controlled the depositional setting of the Smackover Formation, is described as a carbonate ramp that gradually dips south to southwest [8-9]. Deposition of the Smackover Formation in southwest Alabama was heavily influenced by local paleotopography, salt tectonics, and adjacent basins [8-9].

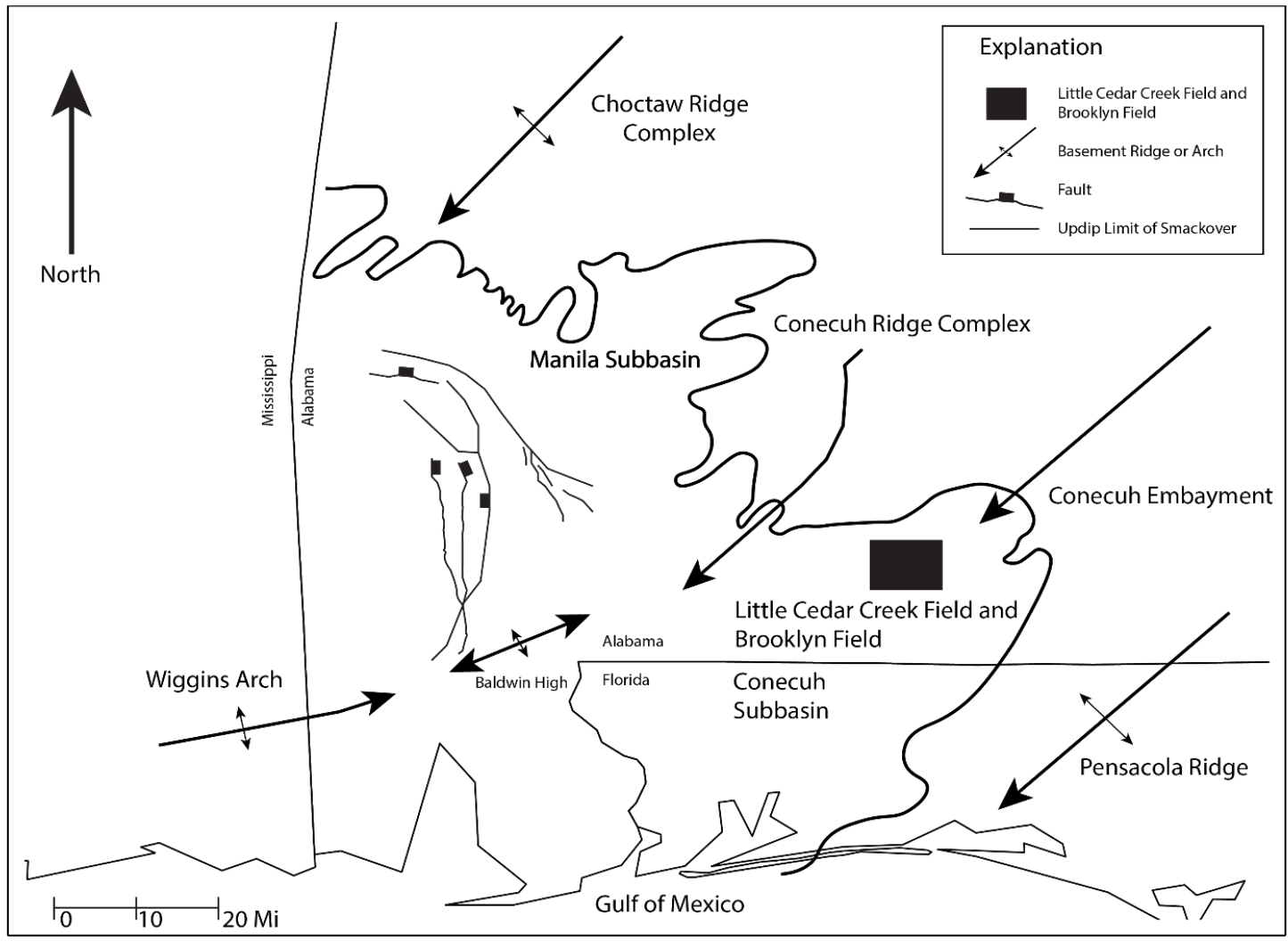

Figure 1. Paleography of southwest Alabama. (Original [5]. Modified from [6-7]).

Regional Stratigraphy 
The Upper Jurassic stratigraphic units within the region model a conformable and transgressive sequence consisting of clastics, carbonates, and evaporates [3,5]. Each unit oversteps the preceding one and pinches out gradually moving landward. This is interpreted as coastal onlap due to an eustatic sea-level rise [3]. Smaller regressive episodes have been identified within the overall transgressive cycle of the Upper Jurassic sequence $[3,10]$. The Haynesville Formation, Smackover Formation, and the Norphlet Formation define the regional Upper Jurassic units (Figure 2).

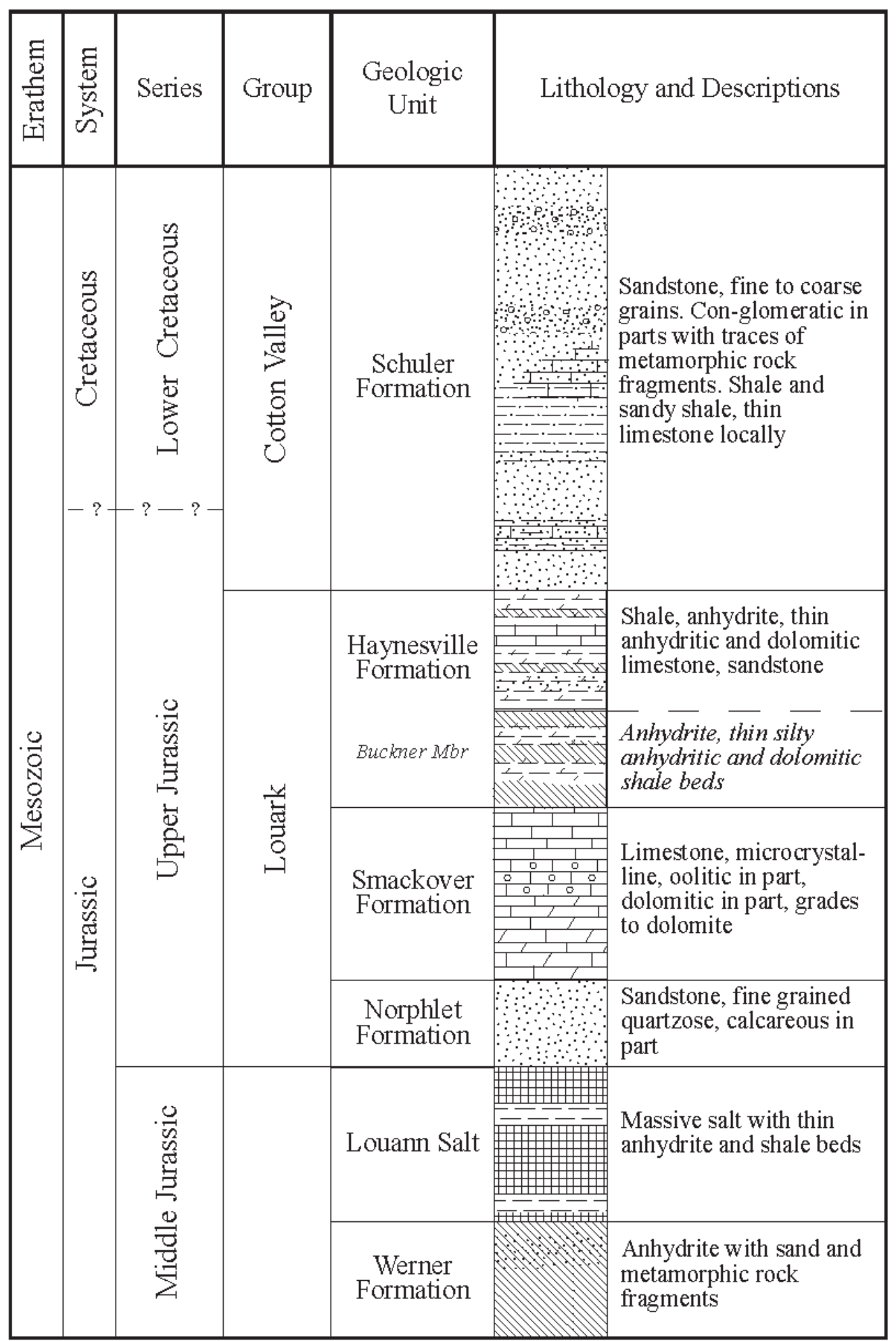

Figure 2. Regional Jurassic stratigraphy of Little Cedar Creek Field and Brooklyn fields (adapted from [4]). 


\section{Norphlet Formation}

The Norphlet Formation stratigraphically underlies the Smackover Formation. The formation is composed mostly of sandstones and conglomeratic sandstones of varied lithology that are influenced by the source of the clastics, transporting agent, and position within the basin [3]. In southwest Alabama, the Norphlet Formation is composed of fine-to medium-grained, well-sorted mature sandstone. Grains are commonly well-rounded and coated with hematite. Because of high-angle cross-bedding and the lack of detrital clay matrix, these sandstones have been interrupted as eolian sands. These eolian sediments grade laterally updip in a northeast trend into a section of siltstones, arkosic sandstones, and conglomeratic sandstones that are commonly poorly sorted. This is due to irregular alterations of eolian and alluvial-fluvial lithofacies along a northwest-southwest belt. Within Little Cedar Creek and Brooklyn fields, the top of the Norphlet Formation consists of conglomeratic-brecciated sandstones composed of igneous and metamorphic pebbles and are interpreted to represent deposition in coalescing alluvial fans and fluvial systems [11].

\section{Smackover Formation}

The Smackover Formation is defined as an Upper Jurassic (Oxfordian Age) unit consisting of limestones and dolostones. Stratigraphically the Smackover Formation uncomformably overlies the Norphlet Formation, bounded by either a gradational or sharp contact [8]. In southwest Alabama, approximate depths to the Smackover ranges between 5,000 feet to 20,000 feet. Three general lithofacies are recognized for the Smackover Formation in the surrounding Gulf of Mexico area: the lower, upper, and clastic members [13].

The lower member is described as a thin intertidal to subtidal series of laminated carbonate mudstone and peloidal oncolitic wackestone and packstone [8]. The middle unit is a thick interval of subtidal to supratidal laminated carbonate mudstone with interbedded peloidal and skeletal wackestone and packstone. Indications of subtidal sequences are found throughout the laminated carbonate mudstone. The upper unit is described as a series of subtidal to intertidal oolitic grainstones and packstones that are interbedded with laminated carbonate mudstone. Throughout the upper Smackover, an algal boundstone is associated with local paleohighs, such as the Choctaw and Conecuh ridge complexes [8].

\section{Harnesville Formation}

The Haynesville Formation is a Kimmeridgian-age unit composed of evaporitic deposits and anhydritic shale and sandstone [4]. The Haynesville Formation is divided into three separate units: lower, middle, and upper. The lower unit is defined as the Buckner Anhydrite member, which conformably overlies the Smackover Formation [8]. The Buckner Anhydrite member consist of massive anhydrite with intercalated dolomite beds. If the massive anhydrite is not present, the lower part of the Haynesville consists of anhydritic shale, sandstone, thin anhydrite beds, and salt stringers. The middle unit is described as interbedded sandstones, shales, and anhydrites. The upper unit of the Haynesville Formation is composed of interbedded carbonate mudstones, dolomitic limestones, sandstones, shales, and anhydrites [8].

\section{Local Stratigraphy}

The Upper Smackover defines southwest Alabama and is characterized by seven distinct lithofacies within Little Cedar Creek and Brooklyn fields. Lithofacies descriptions were based on petrographic analysis conducted by [13] and is generalized in Table 1.

\section{Petroleum System}

The Smackover Formation is one of the most productive oil and gas units in Alabama, eastern Mississippi, and the Florida panhandle. Smackover reservoirs are characterized by combination traps including salt anticlines and stratigraphic traps, faulted salt anticlines, and extensional fault 
traps that relate to the updip limit of the Louann Salt deposition [8]. Hydrocarbon accumulation within Little Cedar Creek and Brooklyn fields has been defined as a dual-reservoir, stratigraphic trap near the updip depositional limit of the Smackover [2]. The two reservoir facies within the Smackover Formation in Little Cedar Creek and Brooklyn fields are characterized as a leached subtidal microbial (thrombolite) boundstone (lower reservoir) and a peloidal-oolitic shoal grainstone-packstone (upper reservoir) [13]. The dual-reservoir system of Little Cedar Creek and Brooklyn are vertically separated by a lime mudstone and are not in communication [2]. The XRF plays an important role in characterizing these facies.

Table 1. The seven lithofacies of the Upper Smackover Formation in southwest Alabama (adapted from [13].

\begin{tabular}{|c|c|c|c|c|c|c|}
\hline Facies & Lithology & Color & $\begin{array}{l}\text { Accessory } \\
\text { Minerals }\end{array}$ & Texture & Cement & $\begin{array}{l}\text { Depositional } \\
\text { Environment } \\
\end{array}$ \\
\hline S-1 & $\begin{array}{l}\text { Limestone } \\
\text {-Dolostone }\end{array}$ & $\begin{array}{l}\text { Grey - } \\
\text { Light } \\
\text { Grey }\end{array}$ & $\begin{array}{l}\text { Dolomite, } \\
\text { Anhydrite, } \\
\text { Gypsum, Silt }\end{array}$ & $\begin{array}{l}\text { Mudstone } \\
\text {-Wackestone }\end{array}$ & $\begin{array}{l}\text { Calcite - } \\
\text { Anhydrite }\end{array}$ & $\begin{array}{c}\text { Shallow - } \\
\text { Water, Lagoon } \\
\text { Environment, } \\
\text { Low Energy }\end{array}$ \\
\hline $\mathrm{S}-2$ & Limestone & Grey & $\begin{array}{l}\text { Monocrystalline } \\
\text {-Polycrystalline } \\
\text { Quartz \& Volcanic } \\
\text { Pebbles less than } \\
\text { 2cm }\end{array}$ & $\begin{array}{c}\text { Rudstone-Floatst } \\
\text { one - small } \\
\text { interval of } \\
\text { Grainstone }\end{array}$ & $\begin{array}{l}\text { Sparry } \\
\text { Calcite }\end{array}$ & $\begin{array}{l}\text { Tidal Channel } \\
\text { Environment }\end{array}$ \\
\hline $\mathrm{S}-3$ & $\begin{array}{l}\text { Partially } \\
\text { Dolomitized } \\
\text { Limestone }\end{array}$ & $\begin{array}{l}\text { Tan - } \\
\text { Grey }\end{array}$ & $\begin{array}{l}\text { Calcite \& Minor } \\
\text { Dolomite Rhombs }\end{array}$ & $\begin{array}{l}\text { Grainstone - } \\
\text { Packstone - } \\
\text { Mudstone }\end{array}$ & $\begin{array}{l}\text { Sparry } \\
\text { Calcite }\end{array}$ & $\begin{array}{l}\text { High Energy, } \\
\text { Subaqueous, } \\
\text { Intertidal Shoal } \\
\text { Environment }\end{array}$ \\
\hline S-4 & Limestone & $\begin{array}{l}\text { Grey - } \\
\text { Dark } \\
\text { Grey }\end{array}$ & Dolomite & $\begin{array}{l}\text { Wackestone - } \\
\text { Mudstone - } \\
\text { Packstone }\end{array}$ & Calcite & $\begin{array}{c}\text { Deep - Water, } \\
\text { Subtidal } \\
\text { Marine } \\
\text { Environment }\end{array}$ \\
\hline S-5 & Limestone & $\begin{array}{l}\text { Grey - } \\
\text { Dark } \\
\text { Grey }\end{array}$ & Dolomite & $\begin{array}{l}\text { Packstone, } \\
\text { Wackestone }\end{array}$ & Calcite & $\begin{array}{c}\text { Subtidal } \\
\text { Marine } \\
\text { Environment }\end{array}$ \\
\hline S-6 & Limestone & $\begin{array}{l}\text { Grey - } \\
\text { Tan \& } \\
\text { Grey - } \\
\text { Light } \\
\text { Grey }\end{array}$ & Dolomite & Boundstone & $\begin{array}{l}\text { Sparry } \\
\text { Calcite }\end{array}$ & $\begin{array}{l}\text { Low-Energy } \\
\text { Shallow - } \\
\text { Water } \\
\text { Environment }\end{array}$ \\
\hline S-7 & $\begin{array}{l}\text { Limestone } \\
\text {-Dolostone }\end{array}$ & $\begin{array}{l}\text { Grey - } \\
\text { Reddish } \\
\text { Pink }\end{array}$ & Dolomite \& Silt & $\begin{array}{l}\text { Mudstone - } \\
\text { Wackestone }\end{array}$ & $\begin{array}{l}\text { Sparry } \\
\text { Calcite }\end{array}$ & $\begin{array}{l}\text { Rapid Marine } \\
\text { Transgression }\end{array}$ \\
\hline
\end{tabular}

\section{Materials and Methods}

The Alabama Geological Survey and the Alabama Oil and Gas Board provided the materials used in this study. Materials consisted of rock core samples, rock core analyses, and geophysical logs of the Smackover Formation.

\subsection{Well Selection and Sample Preparation}

Eight wells were selected for scanning in six-inch intervals using a portable XRF device (Table 2). Figure 3 shows the location of the wells from which the core scans were conducted. We selected the wells based on location and availability of data of the Smackover Formation. The cores were 
one-third slabbed providing a flat surface for scanning. This allowed for a fast workflow and consistent instrument orientation. Cedar Creek Land \& Timber 33-10 \#1 and Johnson-Stewart 32-12 \#1 were tested for core sample preparation. Using a clean, dry, 2-inch brush, the sample was cleaned for scanning. This method detected elements not normally associated with carbonate-dominated lithologies, such as barium. However, barium is sometimes a component in drilling fluids. We modified our scan specimen preparation by cleaning the surface of each core slab with deionized water. Further testing showed no detectable barium so we assumed the dust on the core was drilling fluid related. The standard preparation for each core box was to mist each length of slabbed core with deionized water and wipe clean with a cloth, being careful not to damage the surface or edge of core.

Table 2. List of the wells used for this study.

\begin{tabular}{ccccccc}
\hline \multirow{2}{*}{ Permit \# } & Well Name & $\begin{array}{c}\text { Field } \\
\text { Name }^{1}\end{array}$ & Status & Type & Longitude $^{3}$ & Latitude $^{3}$ \\
\hline 15934 & Johnson-Stewart 32-12 \#1 & BK & DA & OIL & -86.78270 & 31.26628 \\
16453 & Godwin 31-3 & BK & PR & OIL & -86.79727 & 31.27349 \\
16686 & Cedar Creek Land \& & BK & PR & OIL & -86.85973 & 31.26680 \\
& Timber 33-10 \#1 & & & & & \\
$16882-B$ & Cedar Creek Land \& & BK & DA & OIL & -86.74166 & 31.28043 \\
& Timber 27-15 \#1 & & & & & \\
$17011-B$ & Benjamin 26-4 & BK & PR & OIL & -86.83619 & 31.29008 \\
14309 & McCreary 13-16 & LCC & PR & OIL & -86.80659 & 31.30684 \\
$16327-B$ & Craft-Ralls 28-16\#1 WI & LCC & CV & OIL & -86.75441 & 31.36430 \\
$17045-B$ & Craft-Barrow 12-8 \#1 & LCC & PR & OIL & -86.70495 & 31.41526 \\
\hline
\end{tabular}

${ }^{1}$ BK = Brooklyn; LCC = Little Cedar Creek. ${ }^{2} \mathrm{CV}=$ Converted; DA = Dry and Abandoned; PR = Producing.

${ }^{3}$ Geographic coordinates in WGS84.

\subsection{X-ray fluorescence}

$\mathrm{X}$-ray fluorescence $(\mathrm{XRF})$ is based on the phenomenon that atoms will emit X-ray photons when charged by an outside energy source. The contact between high-energy $X$-rays and electrons from the inner electron shell will eject an electron from that shell. With a lower energy slot now available, an electron from a higher energy shell shifts to fill the vacancy. The surplus of energy is emitted (fluoresced) as a secondary photon of X-ray energy, typically from $1-5 \mathrm{keV}$ for lighter elements (e.g. $Z=4-24$; Be to $\mathrm{Cr}$ ) and approximately $1-15 \mathrm{keV}$ for heavier elements (e.g. $Z=25-95 ; \mathrm{Mn}$ to Am). The loss of energy emits radiation from the inner electron shell, which are X-ray photons that classifies the elements. The concentration of the element is defined by the count rate of emitted X-rays per unit time known as scintillation.

To employ the XRF method, we used the Bruker TRACER 5i (Figure 4). It is a handheld portable non-destructive energy dispersive X-ray fluorescence (ED-XRF) spectrometer capable of collecting elemental concentrations on most sample surfaces. Data collected by the TRACER $5 \mathrm{i}$ are reported in counts per second (cps) then processed to parts per million ( $\mathrm{ppm}$ ) or weight percent (wt\%) using a selected calibration. The TRACER $5 \mathrm{i}$ has available many calibrations, and user-created calibrations are possible given there is an adequate number of knowns. The calibration applied for this study was the mudrock duel (updated 2017) calibration provided by Bruker. The rock core samples were scanned every six inches with no filter over the collimator. Resulting fluorescence spectra were processed and matched using the selected calibration. Both major and minor elements were reported in units of the parts per million. Selected results are shown in Table 3. 


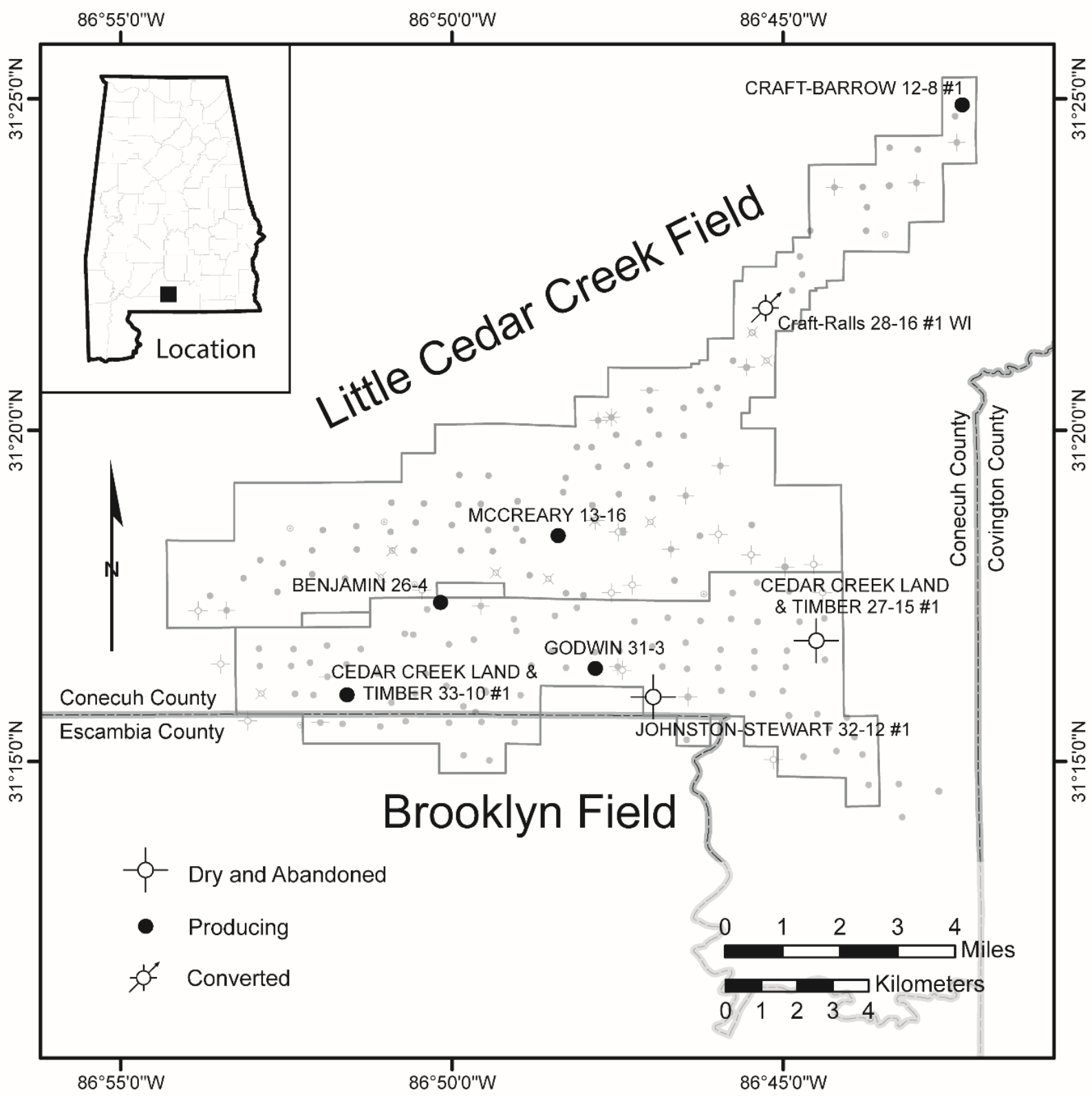

Figure 3. Petroleum wells used from the Little Cedar Creek (northern) and Brooklyn (southern) fields for this study in southern Alabama, United States. All wells in both fields are shown in muted tone as of November 2018. Datum of geographic coordinate is NAD83.

Table 3. Major and Minor elements that are detectable by XRF.

\begin{tabular}{cc}
\hline Major Elements & Minor (Trace) Elements \\
\hline $\mathrm{Si}, \mathrm{Ti}, \mathrm{Al}, \mathrm{Fe}, \mathrm{Mn}, \mathrm{Mg}, \mathrm{Ca}$, & $\mathrm{Ba}, \mathrm{Ce}, \mathrm{Co}, \mathrm{Cr}, \mathrm{Cu}, \mathrm{Ga}, \mathrm{La}, \mathrm{Nb}, \mathrm{Ni}$, \\
$\mathrm{Na}, \mathrm{K}, \mathrm{P}$ & $\mathrm{Rb}, \mathrm{Sc}, \mathrm{Sr}, \mathrm{Rh}, \mathrm{U}, \mathrm{V}, \mathrm{Y}, \mathrm{Zr}, \mathrm{Zn}$ \\
& \\
\hline
\end{tabular}

\subsection{Limestone chemostratigraphy}

Chemostratigraphy is the geochemical classification and correlation of sedimentary strata by using major and trace element geochemistry. It is an especially valuable method when applied to sequences with poor biostratigraphic control [14]. A fundamental aspect of chemostratigraphy is its ability to be correlated both vertically and laterally with enhanced confidence. Chemostratigraphic zonation may be correlated to the facies identified in the Smackover Formation. 


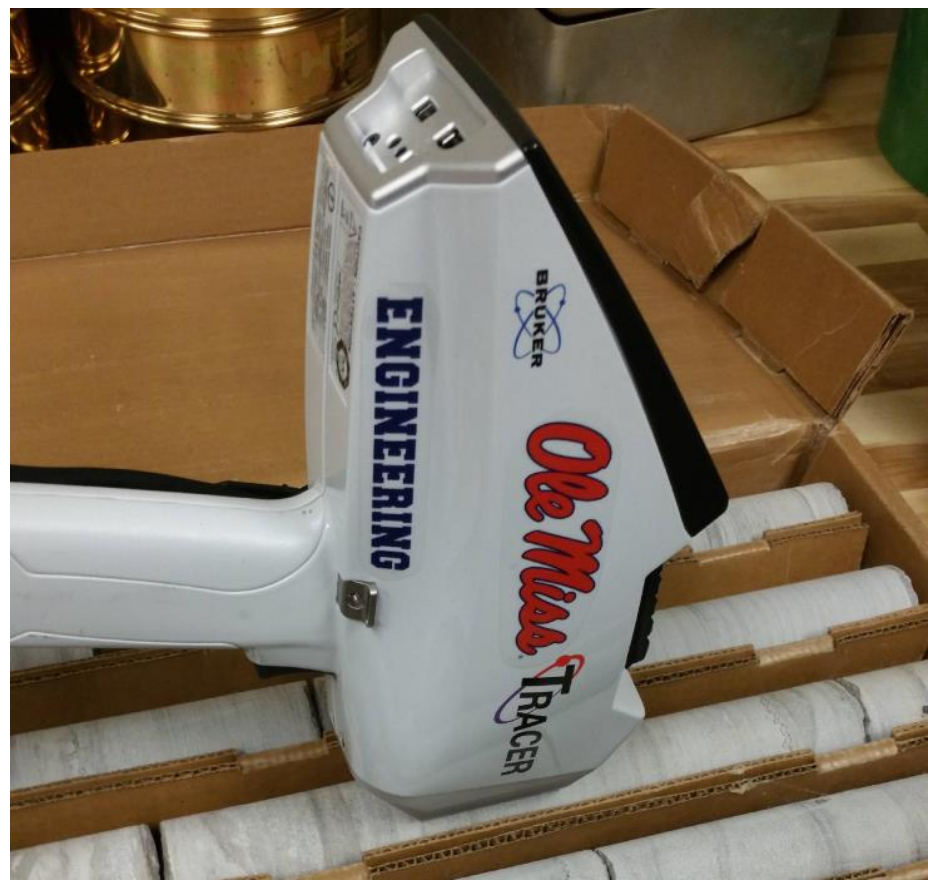

Figure 4. Handheld Bruker Tracer 5i XRF.

Table 4. Sample of Cedar Creek Land \& Timber 33-10 \#1 and XRF counts values recorded with respect to depth.

\begin{tabular}{ccccccc}
\hline Sample & Depth $(\mathbf{f t})$ & $\mathbf{M g}$ & Al & Si & S & Ca \\
\hline 300 & $11,965.0$ & 21,820 & 2,082 & 0 & 4,064 & 361,470 \\
301 & $11,965.5$ & 12,425 & 4,036 & 1,494 & 1,443 & 345,780 \\
302 & $11,967.0$ & 10,009 & 0 & 0 & 858 & 273,992 \\
303 & $11,967.5$ & 12,315 & 1,329 & 0 & 2,248 & 307,540 \\
304 & $11,968.0$ & 20,477 & 0 & 0 & 581 & 178,131 \\
305 & $11,968.5$ & 24,128 & 3,165 & 13,328 & 18,585 & 264,688 \\
306 & $11,969.0$ & 17,714 & 18,255 & 62,223 & 19,592 & 226,486 \\
\hline
\end{tabular}

\subsection{Porosity}

In petroleum systems, porosity is one of the most important reservoir properties to characterize. In this study we estimated the core porosity and used geophysical logs to predict the porosity at depth. From the core analyses, porosity values were estimated for the well logs and tabulated with associated depth (Table 5). For true comparison of footage, the offset between total vertical depth (TVD) and the measured depth (MD) was corrected using the gamma ray logs for each well. These corrected data can be found with the supplemental material.

Predicted porosity was calculated from neutron porosity and density porosity logs. The neutron log and density log tend to show similar formation parameters and porosity. However, due to the effect of lithology on the neutron absorption, the predicted porosity value may need correction. Using a common cross-plot method, the neutron log versus the density log, the points will plot with predicted porosity and lithology. Predicted porosity figures will assist in realigning the offset core back to the correct depth from gamma ray logs. For example, total offset in Cedar Creek Land \& Timber 33-10 \#1 is 15.6 feet (Table 6).

\section{Results}

Data from the XRF was tabulated by sample, depth, and elemental concentration. These tables are provided as supplemental materials. An example of the data is listed in Table 4 . Figure 5 shows the log generated for major elements with lithofacies defined for Cedar Creek Land \& Timber 33-10 $\# 1$ well. 
Table 5. Sample of true porosity values from Cedar Creek Land \& Timber 33-10 \#1 from core analysis.

\begin{tabular}{ccc}
\hline Sample & Depth (ft) & Porosity \\
\hline 1 & $-11,965.5$ & 0.7 \\
2 & $-11,966.5$ & 0.3 \\
3 & $-11,967.6$ & 0.3 \\
4 & $-11,968.5$ & 0.8 \\
5 & $-11,968.8$ & 7.3 \\
\hline
\end{tabular}

Table 6. Sample of predicated porosity values with respect to depth based on the neutron and density porosity values from Cedar Creek Land \& Timber 33-10 \#1.

\begin{tabular}{cccc}
\hline Depth (ft) & Neutron Porosity & Density Porosity & $\begin{array}{c}\text { Predicted } \\
\text { Porosity }\end{array}$ \\
\hline 11,965 & 3 & 3 & 3 \\
11,966 & 36 & 6 & 0 \\
11,968 & 45 & 36 & 0 \\
11,970 & 21 & 21 & 21 \\
11,972 & 21 & 24 & 23 \\
\hline
\end{tabular}

\section{Multiple Regression Analysis}

Using core porosity data, predicted porosity, and elemental data from the XRF analysis a multiple regression analysis was preformed to determine a correlation between the variables. This was conducted on each of the eight wells in the investigation. Using the following relationship:

$$
\hat{Y}=a_{0}+a_{1} x_{1}+a_{2} x_{2}+\cdots+a_{i} x_{i}
$$

where $\hat{Y}$ is the expected value of the dependent variable, $x_{i}$, is equal to a constant term plus the sum of a series of independent variables. The dependent variable, $x_{1}$ for the multiple regression was selected as core porosity and the $x_{1-12}$ variables are the twelve elements selected for this study. The multiple regression analysis was conducted in three separate series for sensitivity analysis, in which individual sample of the elements compared to porosity. For the first series of ANOVA, no restrictions were used and the entire sample population was used. The second series of ANOVA excluded outlier samples greater than four standard deviations from the sample mean $(< \pm 4 \sigma)$. The final series further restricted outliers by excluding samples greater than two standard deviations $(< \pm 2 \sigma)$. The summary of the ANOVA tables is provided in Table 7 .

\section{Discussion and Conclusions}

The results from the multiple regression indicate that the elements aluminum, calcium, iron, silica, and titanium are the significant elements when compared to porosity. The relationship between these various elements and porosity can be separated into two categories and compared to previous work by [15].

\section{Category 1: paleoenvironment}

The first category distinguishes the paleoenvironment of the Smackover Formation. The depositional setting of the Smackover Formation was carbonate ramp similar to the western Persian Gulf. The microbial buildups, shoal grainstones, and sabkha environments resemble the overall vertical facies of the Smackover Formation in Little Cedar Creek and Brooklyn fields. The elements aluminum, iron, silicon, and titanium result from foreland aeolian dunes transporting clay and dust size particles. The combination of aluminum, iron, and silicon can be related to the kaolinite and 

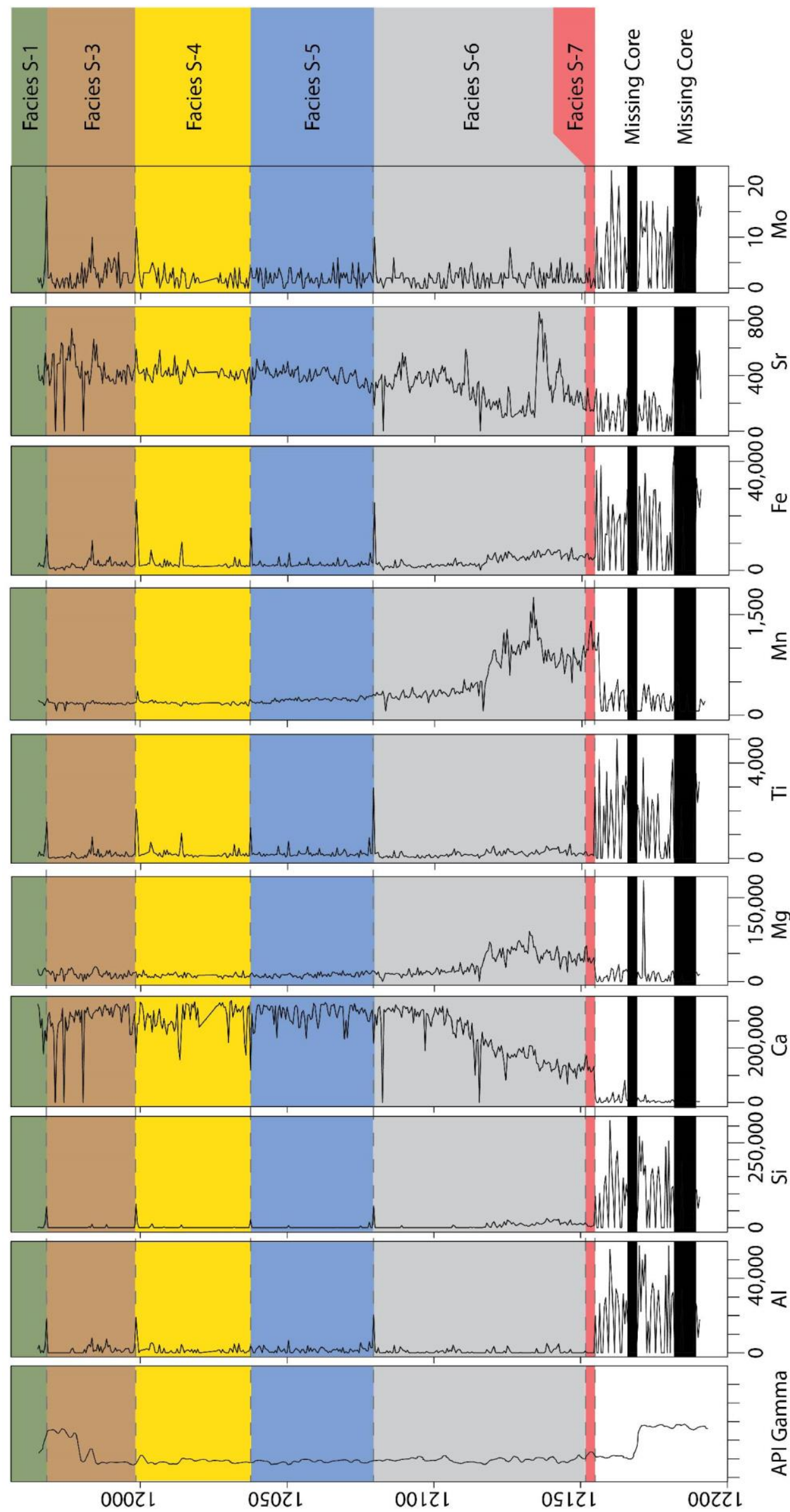

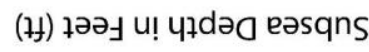

\section{$\stackrel{8}{8}$
$\frac{0}{0}$
$\frac{0}{\alpha}$
$\frac{1}{<}$}


Figure 5. Pervious Page. Cedar Creek Land \& Timber 33-10 \#1 elemental logs generated from selected XRF data with defined lithofacies. All elemental values are reported in parts per million (ppm).

illite clay minerals. Titanium and silicon can relate to dust size particles. Deposition of thin clay and dust stringers between lithofacies occurred between transgression and smaller regression stages when the overall wave energy was calmer (Figures 6 and 7). Overall, changes between lithofacies can be distinguished based on the elemental distribution logs produced from the XRF results (Figure 5). The gamma ray log documents the formation's gamma radioactivity within the well. Most rocks contain traces of gamma-emitting elements and are radioactive to some degree. The radiation originates from naturally occurring uranium, thorium, and potassium [16]. The elemental contacts between lithofacies are generally undistinguishable in comparison to the gamma ray log within Little Cedar Creek and Brooklyn fields.

Table 7. All elemental data compared to porosity are compiled with various sample exclusions based on standard deviation of sample population. Value listed in increasing atomic number. Elements with a greater significance than $\mathrm{p}$-value $<0.05$ are highlighted.

\begin{tabular}{cc|cc|cc|cc}
\hline $\begin{array}{c}\text { Source of } \\
\text { Variance }\end{array}$ & $\begin{array}{c}\text { Degrees of } \\
\text { Freedom }\end{array}$ & \multicolumn{2}{c|}{ no restrictions (all data) } & \multicolumn{2}{|c|}{ samples $<4 \sigma$} & \multicolumn{2}{c}{ samples $<2 \sigma$} \\
\hline Regression & 12 & 14.40 & 0.000 & 13.94 & 0.000 & 12.11 & 0.000 \\
$\mathrm{Mg}$ & 1 & 3.70 & 0.055 & 0.83 & 0.361 & 2.25 & 0.134 \\
$\mathrm{Al}$ & 1 & 7.03 & 0.008 & 5.94 & 0.015 & 0.94 & 0.333 \\
$\mathrm{Si}$ & 1 & 15.86 & 0.000 & 20.40 & 0.000 & 11.06 & 0.001 \\
$\mathrm{~S}$ & 1 & 1.43 & 0.232 & 0.00 & 0.232 & 0.35 & 0.554 \\
$\mathrm{~K}$ & 1 & 0.38 & 0.540 & 0.46 & 0.540 & 0.00 & 0.979 \\
$\mathrm{Ca}$ & 1 & 6.93 & 0.009 & 6.45 & 0.009 & 5.90 & 0.015 \\
$\mathrm{Ti}$ & 1 & 11.96 & 0.000 & 12.43 & 0.000 & 10.23 & 0.001 \\
$\mathrm{Mn}$ & 1 & 0.27 & 0.605 & 2.00 & 0.605 & 1.71 & 0.001 \\
$\mathrm{Fe}$ & 1 & 4.65 & 0.031 & 0.98 & 0.031 & 4.98 & 0.026 \\
$\mathrm{Sr}$ & 1 & 1.99 & 0.159 & 0.49 & 0.159 & 0.03 & 0.855 \\
$\mathrm{Zr}$ & 1 & 1.28 & 0.259 & 0.91 & 0.250 & 0.00 & 0.970 \\
$\mathrm{Mo}$ & 1 & 3.38 & 0.066 & 1.08 & 0.066 & 0.71 & 0.401 \\
\hline
\end{tabular}

Category 2: diagenetic modifications

The second category is identifying the diagenetic effects of the upper and lower reservoirs that controlled porosity development. Diagenetic modification within the Smackover Formation have undergone a complex alteration that is described as eogenetic diagenetic zone.

The eogenetic zone is described by the sediment influenced by surface fluids of marine, meteoric, or brine origin. This diagenetic zone ultimately enhanced porosity through dissolution, related to calcium, and dolomitization, which is associated to the element iron, magnesium, and manganese.

\section{Marine Phreatic Zone}

Within the Smackover Formation, eogenetic diagenesis occurs in three separate eogenetic zones. The marine phreatic zone is described as the first eogenetic zone. Diagenetic alteration of ooids and other allochems within the upper reservoir, facies S-3, began soon after deposition. Deposition in slightly calm waters are related to extensive micritization. In the upper section of facies S-3, biogenic micritization is most noticeable where many ooids have been moderately to entirely micritized. Micritization generated micro-porosity within the ooids making later diagenetic replacement or dissolution more prone [15].

Cementation that occurs within the marine phreatic zone is described as fibrous to bladed thin crust and is usually thicker in oolitic grainstones and thinner in oncolitic and peloidal grainstones. 
This relates to a surge of water circulation in higher energy ooid shoal environments, resulting in marine phreatic cements that generally define overall lithology of less than 5 percent [15]. This suggests that sedimentation in the upper Smackover was abrupt and open to marine phreatic environment for a short period of time.

ED-XRF data suggests relative enrichments in iron, titanium, and potassium may be related to deposition in relatively restricted marine waters. High-resolution ED-XRF data may be most useful in creating a first order geochemical framework to be used to determine or wave dispersion XRF (WD-XRF) may need to be employed to better distinguish elements.

\section{Terrigenous}
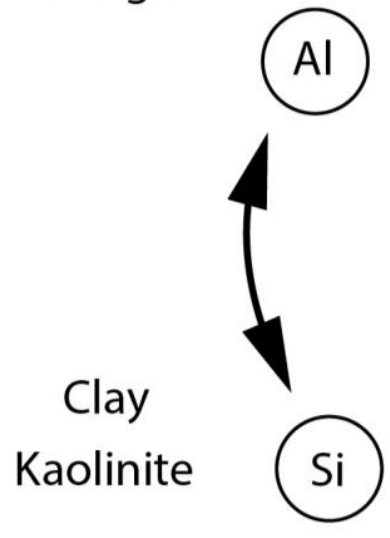

\section{Limestone}
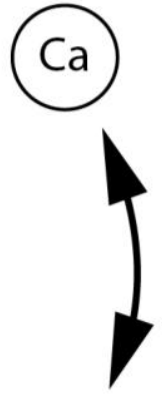

$\phi$ increases

Dolomite

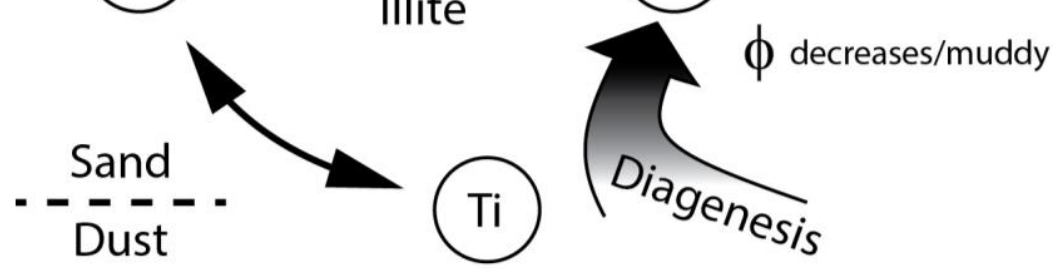

Figure 6. Shows the five elements (aluminum, calcium, iron, silicon, and titanium) with most significance $(p$-value $<0.05)$ from the multiple regression and relates to depositional environment

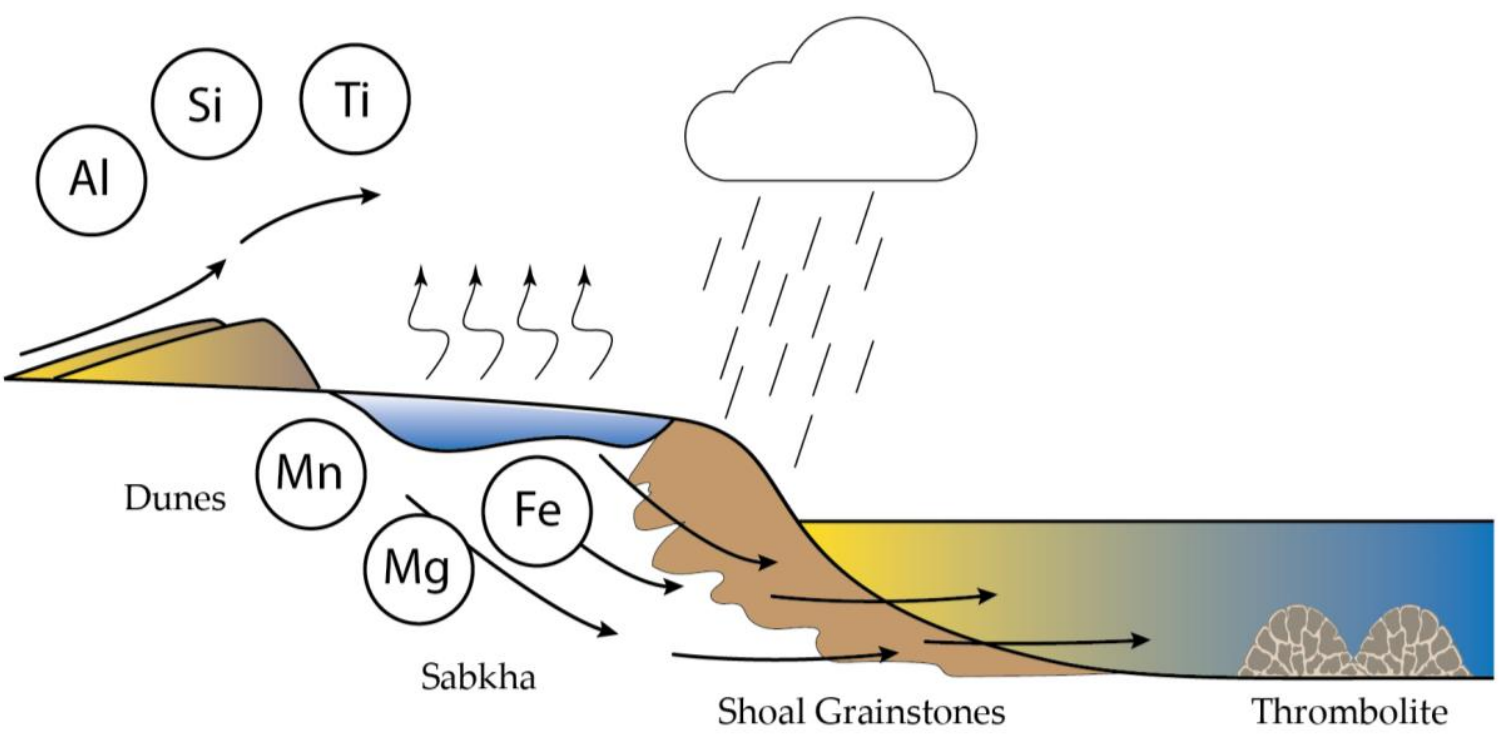

Figure 7. Effects of various elements within the depositional setting of the paleoenvironment of the Smackover Formation.

Supplementary Materials: The following are available online at www.mdpi.com/xxx/s1, Figure S1: title, Table S1: title. 
Author Contributions: conceptualization, L.Y. and G.E.; methodology, R.E. and L.Y.; validation, R.E. and L.Y.; formal analysis, R.E.; resources, G.E. and L.Y..; data curation, L.Y.; writing-original draft preparation, R.E.; writing-review and editing, L.Y., R.E., and G.E.; visualization, R.E. and L.Y.; supervision, L.Y..; project administration, L.Y.; funding acquisition, G.E.

Funding: This research was partially funded by the Mississippi Mineral Resource Institute (MMRI).

Acknowledgments: We would like to thank Camilla Musgrove at the Alabama Oil and Gas Board and Marcella McIntyre with the Alabama Geological Survey, Tuscaloosa, Alabama and Dr. Lou Zachos from the University of Mississippi for his discussions with paleo-depositional environments and potential diagenetic modifications to the Smackover Formation were exceedingly valuable.

Conflicts of Interest: The authors declare no conflict of interest.

\section{References}

1. Geological Survey of Alabama, State Oil and Gas Board. An Overview of the Little Cedar Creek and Brooklyn Fields. 2012, Available online: http://www2.ogb.state.al.us/documents/misc_ogb/lcc_overview.pdf (accessed on 09 Sep 2018).

2. Mancini, E.A; Benson, D.J.; Hart, B.S.; Balch, R.S.; Parcell, W.C.; Panetta, B.J. Appleton field Case Study (Eastern Gulf Coastal Plain): Field Development Model for Upper Jurassic Microbial Reef Reservoirs Associated with Paleotopographic Basement Structures. AAPG Bulletin 2000, 84 (11), 1699-1717.

3. Salvador, A. Origin and Development of the Gulf of Mexico Basin. The Gulf of Mexico Basin 1991, 389-444.

4. Claypool, G.E.; Mancini, E.A. Geochemical Relationships of Petroleum in Mesozoic Reservoirs to Carbonate Source Rocks of Jurassic Smackover Formation, Southwestern Alabama. AAPG Bulletin 1989, 73 (7), 904-924.

5. Mink, R.M.; Bearden, B.L.; Mancini, E.A. Regional Jurassic Geologic Framework of Alabama Coastal Waters Area and Adjacent Federal Waters Area Marine Geology 1989, 90 (1), 39-50.

6. Crevello, P.D.; Harris, P.M. Depositional Models for Jurassic Reefal Buildups. In Proceedings Gulf Coast Section Soc. Econ. Paleont. Mineral. 1984, Third Ann. Research Conf, 57-101.

7. Kopaska-Merkel, D.C. Jurassic Reefs of the Smackover Formation in South Alabama. Geological Survey of Alabama Circular 1951998.

8. Mancini, E.A.; Tew, B.H; Mink, R.M. Jurassic Sequence Stratigraphy in the Mississippi Interior Salt Basin of Alabama Gulf Coast Assoc. of Geol. Soc. Trans. 1990, 40, 521-529.

9. Kopaska-Merkel, D.C.; Mann, S.D. Pore Facies of Smackover Carbonate Reservoirs in Southwest Alabama Gulf Coast Assoc. of Geol. Soc. Trans. 1991, 41, 374-382.

10. Mancini, E.A.; Benson, D.J. Regional Stratigraphy of Upper Jurassic Smackover Carbonates of Southwest Alabama Gulf Coast Assoc. of Geol. Soc. Trans. 1980, 30, 151-165

11. Heydari, E.; Baria, L.R. Reservoir Characteristics of the Smackover Formation at the Little Cedar Creek Field, Conecuh County, Alabama. Gulf Coast Association of Geological Societies (GCAGS) Annual Convention Lafayette, Louisiana 2006.

12. Heydari, E.; Baria, L.R. Sequence Stratigraphy of the Smackover Formation in the North-Central U.S. Gulf Coast. Gulf Coast Association of Geological Societies (GCAGS) Annual Convention Lafayette, Louisiana 2006.

13. Ridgway, J.G. Upper Jurassicc (Oxfordian) Smackover Facies Characterization at Little Cedar Creek Field, Conecuh County, Alabama. Master of Science, University of Alabama, Tuscaloosa, Alabama 2010.

14. Pearce, T.J.; Besly, B.M.; Wray, D.S.; Wright, D.K. Chemostratigraphy: A Method to Improve Interwell Correlation in Barren Sequences-a Case Study Using Onshore Duckmantian/Stephanian Sequences (West Midlands, UK) Sedimentary Geology 1999, 124 (1-4), 197-220.

15. Benson, D. J. Diagenetic Controls on Reservoir Development and Quality, Smackover Formation of Southwest Alabama. AAPG Bulletin 1985, 69 (9), 1417-1417.

16. Rider, M.H.; Kennedy, M. The Geological Interpretation of Well Logs, 3rd Revised ed.; Rider-French Consulting Limited: Cambridge, England, 2011. 